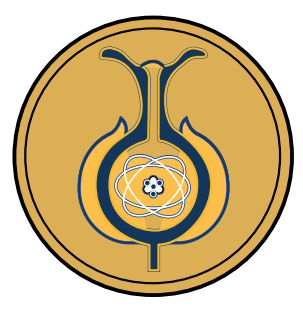

\title{
Nesting of arboreal ants (Hymenoptera: Formicidae) in artificial substrates in coffee plantations in the Colombian Andes
}

\author{
Anidación por hormigas arbóreas (Hymenoptera: Formicidae) en sustratos \\ artificiales en plantaciones de café en los Andes Colombianos.
}

Aninhamento feito por formigas arbóreas (Hymenoptera: Formicidae) em substratos artificiais em cafezais nos Andes Colombianos.

Andrés Jireh López-Dávila ${ }^{1}$, Selene Escobar-Ramírez ${ }^{1,2}$, Inge Armbrecht ${ }^{1}$

Received: Nov/1/2020 • Accepted: Feb/28/2021 • Published: Jul/31/2021

\section{Abstract}

Ants can provide pest biocontrol for coffee crops; however, this ecosystem service may decline in intensively managed plantations due to the loss of nesting resources. Considering how to increase the number of ants, we studied if they nest in different types of artificial substrates attached to coffee bushes both in shade-grown and sun-grown coffee plantations. Three independent tests were conducted at some coffee plantations in southwestern Colombia with the purpose of answering the following questions: 1) Do ants nest in artificial substrates made from recyclable materials? 2) Do the types of substrate (materials and configuration) and coffee management (shade-grown vs. sun-grown coffee) affect colonization rates, richness, and identity of colonizing ants? 3) Does time affect substrate colonization rates? Each experiment independently compared different substrate materials and designs, in both shade and sun-grown coffee. Results showed preference of one of the substrates offered and higher nesting rates in shade-grown plantations. Eight ant species were found nesting in artificial substrates, most of them being arboreal generalists. A higher number of ant species colonized substrates in shade-grown plantations; however, the effect was not statistically significant. Nesomyrmex asper and Crematogaster spp. were always found nesting in both types of plantation. There was a trend to increase nesting activity with time in shade-grown coffee but not in sun-grown coffee. Evidence supports that offering artificial substrates enhances arboreal ant nesting in coffee plantations.

Keywords: Crematogaster; Management of beneficial ants; Management of coffee agroecosystems; Nesting resources; Nesomyrmex

Andrés Jireh López-Dávila, $\triangle$ andresjlopez25@gmail.com, (1) https://orcid.org/0000-0003-2868-3547

Selene Escobar-Ramírez, $\square$ sescobar@usfq.edu.ec, (1) https://orcid.org/0000-0002-1603-4710

Inge Armbrecht, $\square$ inge.armbrecht@correounivalle.edu.co, (1) https://orcid.org/0000-0003-0574-2559

1 Department of Biology, Universidad del Valle, Cali, Colombia.

2 Colegio de Ciencias Biológicas y Ambientales, Herbario de Botánica Económica del Ecuador, Universidad San Francisco de Quito, Quito, Ecuador 


\section{Resumen}

Las hormigas pueden ejercer biocontrol del cultivo de café, pero este servicio puede declinar en plantaciones manejadas intensivamente debido a que se pierden recursos de nidificación. Considerando cómo incrementar las hormigas, estudiamos si estas anidan en diferentes tipos de sustratos artificiales adheridos sobre arbustos de café tanto en cafetales de sombra como de sol. Se realizaron tres exámenes independientes en cafetales del suroccidente colombiano para responder: 1) ¿Anidan las hormigas en sustratos artificiales hechos de materiales reciclables? 2) ¿El tipo de sustrato (material y configuración) y el tipo de manejo del cafetal (sombra vs. sol) afectan la colonización, riqueza e identidad de hormigas? 3) ¿Afecta el tiempo las tasas de colonización de sustratos artificiales? Cada experimento comparó diferentes materiales y diseños, tanto en cafetales de sombra como de sol. Las hormigas anidaron más en uno de los sustratos ofrecidos y hubo mayor nidificación en cafetales de sombra. Ocho especies anidaron en los sustratos artificiales, la mayoría generalistas arbóreas. Un mayor número de especies de hormigas colonizó sustratos en cafetales de sombra, aunque no fue estadísticamente significativo. Nesomyrmex asper y Crematogaster spp. siempre se encontraron anidando en ambos tipos de plantación. La evidencia soporta que se puede ofrecer sustratos artificiales favorece la anidación por hormigas arbóreas en plantaciones de café.

Palabras Clave: Crematogaster; Manejo hormigas benéficas; Manejo agroecosistemas cafeteros; Recursos de nidificación; Nesomyrmex

\section{Resumo}

As formigas podem exercer controle biológico no cultivo do café, porém essa função pode reduzir em plantações manejadas intensivamente, já que os recursos de aninhamento são perdidos. Considerando 0 aumento das formigas, foi estudado se 0 aninhamento se dá em diferentes tipos de substratos artificiais aderidos sobre arbustos de café tanto em cafezais sombreados quanto ensolarados. Foram realizadas três provas independentes em cafezais do sul ocidental colombiano para responder: 1)As formigas se aninham em substratos artificiais feitos de materiais recicláveis? 2) 0 tipo de substrato (material e configuração) e 0 tipo de manejo do cafezal (sombra vs. sol) afetam a colonização, riqueza e identidade das formigas? 3 ) 0 tempo afeta as taxas de colonização de substratos artificiais? Cada experimento comparou diferentes materiais e desenhos, tanto em cafezais sombreados quanto ensolarados. As formigas se aninharam mais em um dos substratos oferecidos e houve maior aninhamento em cafezais sombreados. Oito espécies aninharam-se nos substratos artificiais, a maioria generalistas arbóreas. Um maior número de espécies de formigas colonizou substratos em cafezais sombreados, ainda que não tenha sido estatisticamente significativo. Nesomyrmex asper e Crematogaster spp. sempre foram encontrados se aninhando em ambos os tipos de plantação. A evidência propõe que é possível oferecer substratos artificiais para favorecer 0 aninhamento de formigas arbóreas em plantações de café.

Palavras-chave: Crematogaster; Manejo de formigas benéficas; Manejo agroecossistemas cafeeiros; Recursos de aninhamento; Nesomyrmex 


\section{Introduction}

Coffee crop intensification often involves elimination of associated trees and high agrochemical use, practices which negatively affect the natural diversity associated to the plantations (Armbrecht \& Perfecto, 2003). Traditionally, coffee was planted under a canopy of native trees which protected the plants and soil, and provided habitat for wild fauna such as birds, mammals, and insects. However, some decades ago, a fast conversion and intensive production system was implemented with no tree cover and was highly dependent on agricultural inputs (Perfecto et al., 1996). In Colombia, more than half of the coffee agroecosystems have no shade trees (Jha et al., 2014; Ocampo-Lopez \& Alvarez-Herrera, 2017). This reduction of shade affects the structural complexity of the coffee agroecosystem with negative consequences for the associated biodiversity and its ecosystem services (De La Mora et al., 2015; Philpott \& Armbrecht, 2006).

The lack of shade trees limits the amount of available resources that ants need for nesting (less leaf litter, twigs and trunks) (Armbrecht et al., 2006), thus probably reducing their impact on biological pest control (Philpott \& Armbrecht, 2006). As an alternative, the provision of artificial nesting sites could contribute to an increase in abundance of ants that nest in twigs on shrubs and, therefore, promote both the abundance and diversity of ants, and a more effective biological control of pests on the sites where the artificial nests are located (Guzman et al., 1997; Vidal-Hernández \& Armbrecht, 2009; Hosang et al., 2010; De la Mora et al., 2015). For instance, Guzman et al. (1997) found $98 \%$ control by ants of a pest in oil palms whereas Crematogaster sp. was promoted while Vidal-Hernandez and Armbrecht (2009) found increased ant diversity when bamboo twigs were added to Colombian coffee plantations. Hosang et al. (2010) managed to enhance the predator ant Dolichoderus thoracicus using artificial nesting substrates while De la Mora et al. (2015) found that prey removal by ants on coffee plantations was positively correlated with hollow coffee twigs. Further, heterogeneous nesting resources (substrates) could be important in promoting ant diversity and abundance (Armbrecht et al. 2004; Mottl et al., 2019) Given these studies and the potential of ants as biocontrol agents, an assessment is needed for the type of substrates or the appropriate configurations required to favour ant colonization in a given agroecosystem.

In this study, a total of three field tests were performed in order to assess nesting ability, preferences and colonization rates of ant species in both shaded-grown and sungrown coffee crops, when artificial nesting resources were provided in plantations in southwestern Colombia. First, we tested ant colonization in two different designs of artificial substrate. Based on the best traits of those designs, a third nesting substrate was designed and monitored for ant colonization over time. We hypothesized that the presence of trees in coffee plantations fosters the colonization of artificial substrates by generalist ants, and that a higher percentage of substrates will be colonized by ants over time.

\section{Methods}

\section{Study area}

The sampling site was located in the village of La Venta, Municipality of Cajibio, Cauca Department, Colombia $\left(2^{\circ} 37^{\prime} 24^{\prime \prime} \mathrm{N}\right.$; $\left.76^{\circ} 34^{\prime} 23^{\prime \prime} \mathrm{W}\right)$. The site was located in the 
Alto Cauca Valley at 1,760 m.a.s.1. with annual temperatures between $23.8-27.1{ }^{\circ} \mathrm{C}$ (IDEAM 2015). Three sun-grown and three shade-grown coffee plantations were selected, approximately 1.5 ha each, with 3-year-old coffee shrubs planted 1.5-2.0 $\mathrm{m}$ from each other (Table S1). To differentiate shade-grown from sun-grown coffee plantations, the canopy cover was calculated by means of a GRS Densitometer ${ }^{(\mathrm{TM})}$ at 400 observation points. Canopy cover was $6.2 \%( \pm 9.5 ; n=3)$ in sun-grown coffee vs. $42.3 \%( \pm 6.5 ; n=3)$ in shade-grown coffee. Three independent tests were performed between 24 March and 18 December 2015 on all six plots at different moments. During the sampling period, monthly temperature and average precipitation data were recorded (Figure 1) (IDEAM, 2015). The first test matched a decrease in precipitation, the second was made throughout the dry period, and the third during a transition to the next rainy season. Each of the three tests carried out in the field is described below.

\section{Test 1: PVC covers filled with co- rrugated cardboard (CC) vs. card- board tubes (CT)}

Ant nesting was compared in two types of artificial substrates: polyvinylchloride tubes filled with corrugated cardboard (CC) vs. polyvinylchloride tubes filled with cardboard tubes (CT), on sun-grown and shade-grown coffee plantations (Figure 2a). The CC resembles the cavities found in tree bark where ants forage and nest, and $\mathrm{CT}$ resembles hollow twigs. The PVC cover was a tube $6 \mathrm{~cm}$ in diameter and $30 \mathrm{~cm}$ in length. The CC substrate filling consisted of a $30 \times$ $46 \mathrm{~cm}$ sheet of a tightly rolled $\mathrm{CC}$, forming internal cavities of $0.3 \mathrm{~cm}$ in diameter and 0.4 $\mathrm{cm}$ in height (Packing S.A., Colombia). The CT substrate consisted of five firmly packed CT $($ diameter $=1 \mathrm{~cm}$, length $=30 \mathrm{~cm}$, thickness $=3-4 \mathrm{~mm}$ ) (Figure 2a). On each of the six coffee plantations, 20 focal units of trees with high ant activity were identified. Then, two $\mathrm{CC}$ substrates and two CT substrates

\section{Sampling period}

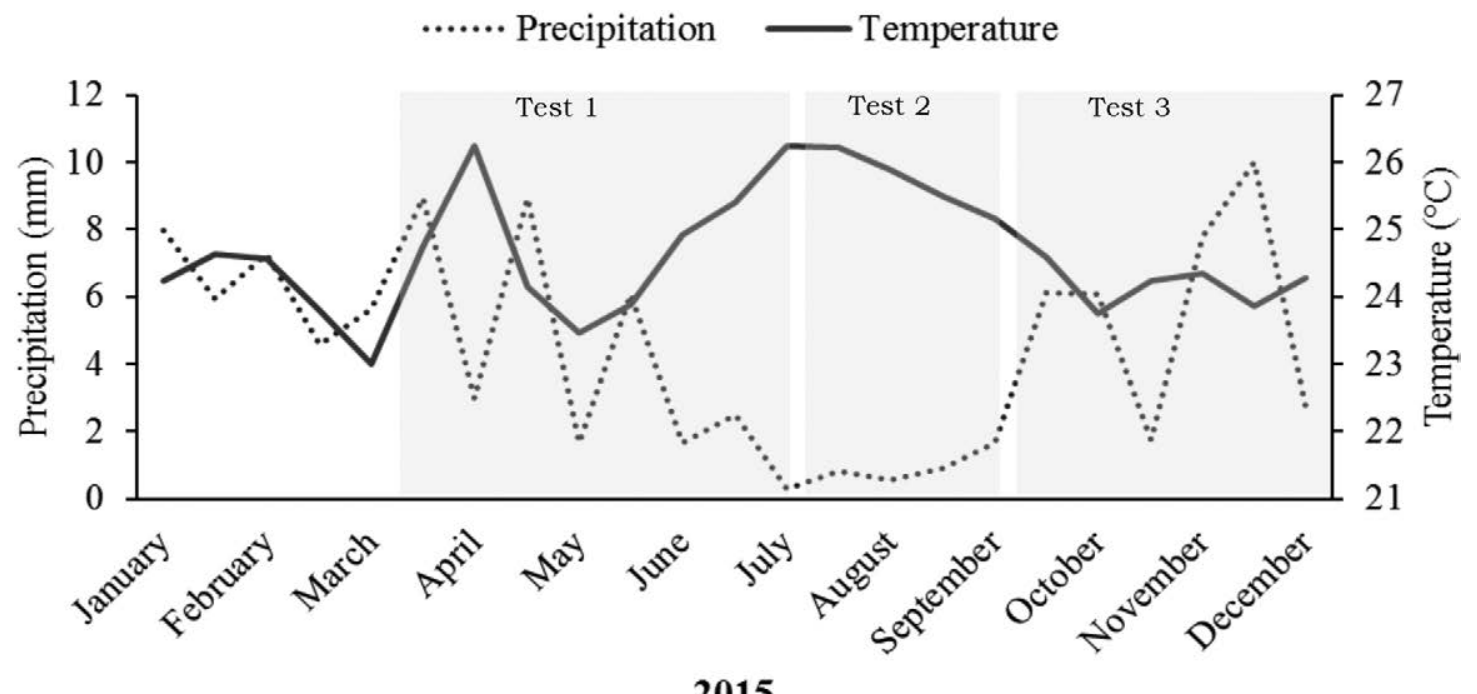

2015

Figure 1. Monthly temperature in ${ }^{\circ} \mathrm{C}$ (black line) and monthly precipitation in mm (dotted line) recorded during 2015, the year when the three independent experiments were performed Source: IDEAM Colombia. 
were placed on four coffee plants surrounding the tree (Figure 2a). Overall, 120 artificial substrates were provided: 60 on shade-grown coffee plots and 60 on sun-grown coffee plots. Substrates were installed from March $21^{\text {st }}$ to $24^{\text {th }}, 2015$ (flowering cycle), and collected between June $28^{\text {th }}$ and July $3^{\text {rd }}$ (fruiting cycle) after three months for inspection to assess colonization.

\section{Test 2: Cover comparison (PVC vs. CC)}

Given the possibility of a 'greenhouse effect' on the interior of the substrates caused by a polyvinylchloride cover, a second test was performed in sun-grown and shade-grown coffee to establish whether this type of cover affected substrate colonization. For this test, we compared ant nesting in substrates with two different covers: polyvinylchloride tube vs. CC covered with a transparent plastic film (Figure 2b). Both covers were filled with the same substrate consisting of CT filled with CC. The same six coffee plots in Test 1 were used for Test 2. In each coffee plot, 13 pairs of contiguous coffee trees with high ant activity were selected, and the two types of substrates were randomly assigned to each coffee tree. A total of 156 artificial substrates were used in this test: 78 on shade-grown coffee plots and 78 on sun-grown coffee plots. Inner substrate temperature was estimated for sun-grown and shade-grown coffee from a total of 30 substrates of each type. The substrates were installed between June $28^{\text {th }}$ and July $3^{\text {rd }}, 2015$ during the fruiting cycle and were collected, uncovered, and inspected between September $12^{\text {th }}$ and $15^{\text {th }}, 2015$ (flowering cycle) to assess ant colonization after two months.

\section{Test 3. Single type of a full cardboard substrate: colonization over time}

In this test, a single substrate type was monitored for ant colonization over time in sun-grown and shade-grown coffee. Based on previous experience with Tests 1 and 2, we designed a substrate covered by CC (to avoid an increase in internal temperature) and filled it with a combination of $\mathrm{CT}$ and CC (to allow nesting by ants of different sizes) (Figure 2c). Specifically, the filling of each substrate consisted of five flattened and tightly packaged CT (diameter $=3 \mathrm{~mm}$; length $=30 \mathrm{~cm}$ ), protected by a $\mathrm{CC}$ cover $(30 \times 36 \mathrm{~cm})$ and wrapped in a transparent plastic film (Figure 2c). At each coffee plot, 40 artificial substrates were fixed (one substrate per coffee plant) and spatially distributed into five rows, each of them containing eight substrates separated from each other by ten coffee plants. A total of 240 substrates were provided: 120 in sun-grown coffee and 120 in shade-grown coffee. Substrates were checked once a month for three months for ant colonization. Substrates were installed between September $12^{\text {th }}$ and $15^{\text {th }}$, 2015 (flowering cycle), collected between December $15^{\text {th }}$ and $18^{\text {th }}, 2015$ (fruiting period). Identification of the ants nesting in the substrates was performed using available guides on Neotropical ants: Fernández and Palacio (2003), Antweb (2014), and Longino (2003). Cephalic capsules were measured for twenty individuals from each nesting species using a SMZ 645 model Nikon stereoscope with magnifying binocular lenses up to $8.0 \times(4.0 \times 2.0)$. 
a)

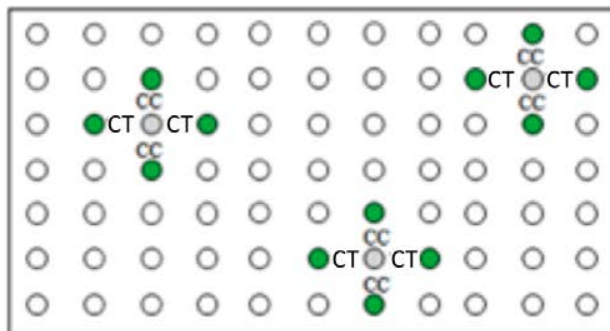

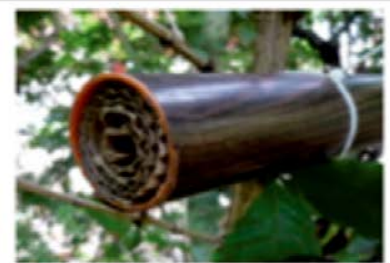

CC

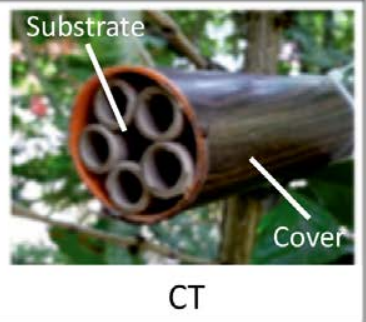

b)

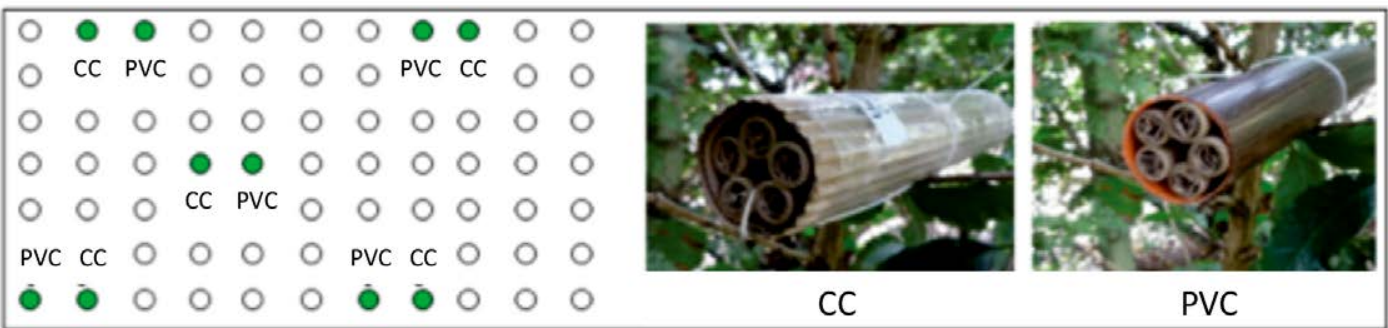

c)

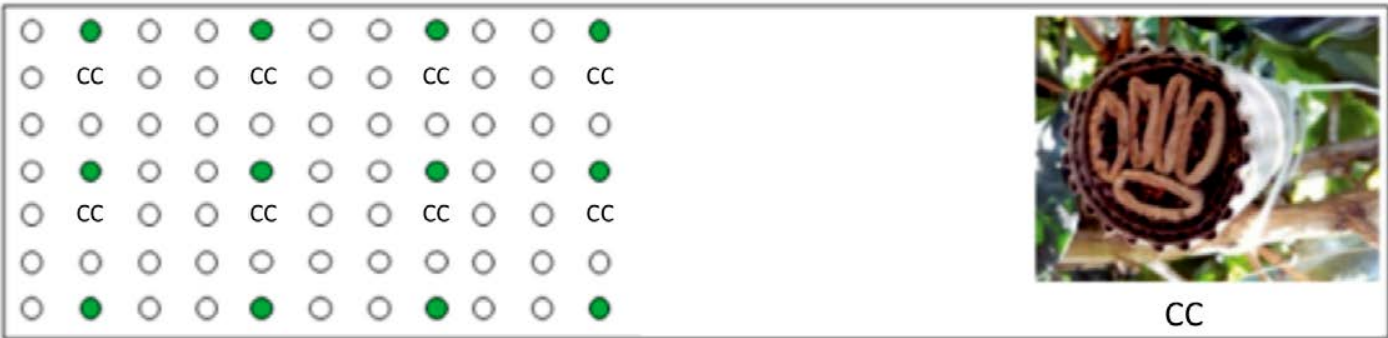

Figure 2. Types of artificial substrates offered and their allocation within the coffee plantation: a) In Test 1, a PVC cover with two types of filling substrate (CC and CT) was placed around trees with high ant activity; b) for Test 2, two different types of covers (PVC vs. CC) for the same substrate filling (CT filled with CC) were compared; $c$ ) in Test 3, a single type of substrate made of CC was evenly distributed in the plantations.

\section{Data analyses}

For the three tests, colonization percentages were estimated as number of colonized substrates over the total of recovered substrates (missing substrates were not considered) and analysed in relation to substrate type and tree cover on the coffee plots.

In Test 1, a generalized linear mixed model (GLMM) was used to assess the effect of substrate type, coffee plot, tree cover type (fixed factors) and focal unit (random factor) on the colonization percentage by ants. The response variable was binary. Only those focal units where at least one substrate of each type was recovered were used. Through this model, we assessed possible interactions between type of substrate and type of arboreal cover.

In Test 2, no statistical analysis was carried out because the independence of the sample units could not be clearly established. Therefore, a descriptive comparison of the treatments was made. The inner substrate temperatures on sun-grown and shade-grown coffee plantations were compared using a $t$-student test.

For Test 3, a chi-square test (Zar, 1999) was used to determine if differences existed in the proportion of colonized substrates 
between sun-grown and shade-grown coffee during the months of substrate monitoring. For the GLMM and chi-square tests, we used the glmer package from the Ime4 library and R Studio software (R Core Team, 2013). For this test, each coffee plantation was considered a sample unit. Colonization preferences by ant species on the different tests were also analysed

\section{Analyses and results}

\section{Test 1: Substrate comparison (CC vs. CT)}

General colonization in the first test was $28.9 \%$. Substrate colonization was not significantly affected by the presence of tree cover on the coffee plantation ( $F$ $\left.{ }_{(1.52)}=0.47 ; p=0.49\right)$. No interaction between type of tree cover and type of substrate was found, indicating that tree cover had no influence on the success of substrate colonization $\left(F_{(4.52)}=1.4162 ; p=\right.$ 0.7081). However, ants showed a nesting preference for the substrate filled with CC compared to $\mathrm{CT}$ on both sun-grown and shade-grown coffee plantations $\left(F_{(1.52)}=\right.$ $6.45 ; p=0.014$ ) (Figure 3 ). The species with the highest number of colonization events were Nesomyrmex asper (52.6\% in shade-grown coffee and $36.4 \%$ in sungrown coffee) and Crematogaster crino$s a(54.5 \%$ in sun-grown coffee but only $10.5 \%$ in shade-grown coffee). Both species nested exclusively inside substrates filled with CC (Supplementary material, Figure S1) and had the smallest cephalic capsules among all the ants found in this experiment (Table 1). Larger Camponotus species were found nesting exclusively inside the CT. The reason for including a measurement of cephalic capsules was because a trend for smaller species nesting in corrugated cardboard was detected. However, there was not enough data to test for differences in ant traits according to substrate features. Barroso et al. (2020), in Brazil, found that different species of Pheidole colonized twigs with different wood anatomy and structure, which suggests that wood structure determines preference for twig occupation.

Table 1. Size of cephalic capsule of ants nesting in Test 1 substrates, and size of entrance to their respective substrate. Average values $\pm S D$ are presented in this table. $N=20$ workers for all species listed.

\begin{tabular}{lcc}
\hline \multicolumn{1}{c}{ Species } & Approx. size of head (mm) & Size of entrance to substrate (mm) \\
\hline Crematogaster crinosa & $0.8( \pm 0.07)$ & 4 \\
Cr. montezumia & $0.74( \pm 0.09)$ & 4 \\
Nesomyrmex asper & $1.16( \pm 0.11)$ & 4 \\
Camponotus sp. 1 & $2.5( \pm 0.29)$ & 10 \\
Camponotus sp. 2 & $2.38( \pm 0.47)$ & 10 \\
Camponotus cf. indianus & $5.1( \pm 1.58)$ & 10 \\
\hline
\end{tabular}


Test 1

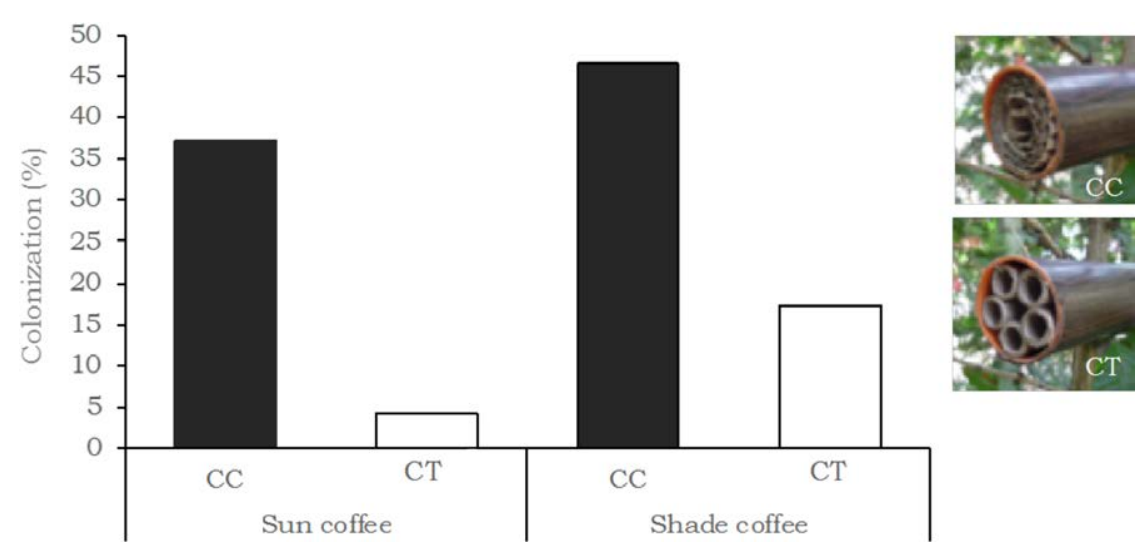

Figure 3. Nesting preferences by ants in Test 1. Percentage of colonization by ants in substrates made using a PVC cover and filled with two different types of filling substrates: CC and CT on sun-grown and shade-grown coffee plots.

\section{Test 2: Cover comparison (corruga- ted cover vs. PVC cover)}

A general colonization of $9.9 \%$ was found, the lowest among all the tests (Figure 4), which coincided with the driest/hottest period in the study (Figure 1). However, this coincidence does not necessarily explain the observed nesting preferences. Ant colonization was $7.5 \%$ in sun-grown coffee and $12.5 \%$ in shade-grown coffee. In sun-grown coffee, a higher colonization percentage was found in CC $(12.5 \%$ for CC vs $2.9 \%$ for PVC), while in shade-grown coffee a similar colonization by ants was found in both substrates $(12.1 \%$ in CC and $12.9 \%$ in PVC). In general, average inner temperature was $2.3-2.7^{\circ} \mathrm{C}$ higher in sungrown coffee than in shade-grown coffee. In sun-grown coffee, temperature inside substrates covered with PVC $\left(27.0^{\circ} \mathrm{C}\right)$ was higher than substrates covered by $\mathrm{CC}\left(26.6^{\circ} \mathrm{C}\right)\left(t_{(14)}=-2.28 ; p=0.0298\right)$; in contrast, substrates on shade-grown plantations showed no differences $\left(t_{(14)}=\right.$ $0.183 ; p=0.855)$. Due to the low number of colonized substrates, the colonization preferences by ants are difficult to detect. Again, N. asper colonized more substrates in sun-grown and shade-grown coffee (Figure S2). Temperatures inside PVC substrates were only significantly higher than those inside CC substrates on sun-grown coffee plantations (Table S2) in contrast to shade-grown coffee where no differences were detected. In shade-grown coffee, the different ant species indistinctively colonized substrates with both cover types. However, in sungrown coffee, $N$. asper never colonized substrates covered with PVC, suggesting a species-specific thermal response to the increased inner temperature due to the PVC cover on plots with low tree cover.

\section{Test 3. Monitoring of a type of arti- ficial substrate over time}

General colonization showed no significant variation over time $\left(\chi_{(1)}^{2}=0.14 ; p\right.$ $=0.71)$. Colonization percentages per month were $13.6 \%, 14.1 \%$, and $17.5 \%$ for the first, second, and third month, respectively (Figure 5). Colonization was higher in shade-grown coffee $\left(\chi_{(1)}^{2}=32.85 ; p=0.95^{*} e^{-9}\right)$ and a trend towards an increase in colonization was observed as time passed (from $18 \%$ to $25 \%$ ). On sun-grown coffee plantations, colonization remained relatively stable over time (6\% to $8 \%)$. Species N. asper, C. crinosa and Camponotus sp.1 were 
found in both sun-grown and shade-grown coffee (Figure S3). N. asper colonized a higher number of substrates in this test, showing the highest colonization percentage in shade-grown coffee, followed by $C$. crinosa.

\section{Discussion}

In general, this research project shows that arboreal generalist ants do use artificial substrates mainly made of recyclable cardboard as an alternative nesting resource on both sun-grown and shade-grown coffee plantations. Low colonization percentages also occurred in the same region where Vidal-Hernandez and Armbrecht (2009) found colonization values of $13.24 \%$ and $6.03 \%$ in artificially added bamboo twigs both in shade-grown and sungrown coffee, respectively. The percentage of colonization was low compared to other studies (Hosang et al., 2010; Mottl et al. 2019), possibly due to a reduction in ant diversity and abundance with elevation (Lach et al., 2010). Although ants are found on almost all continents (except Antarctica), they are mainly found at low latitudes and,
Test 2

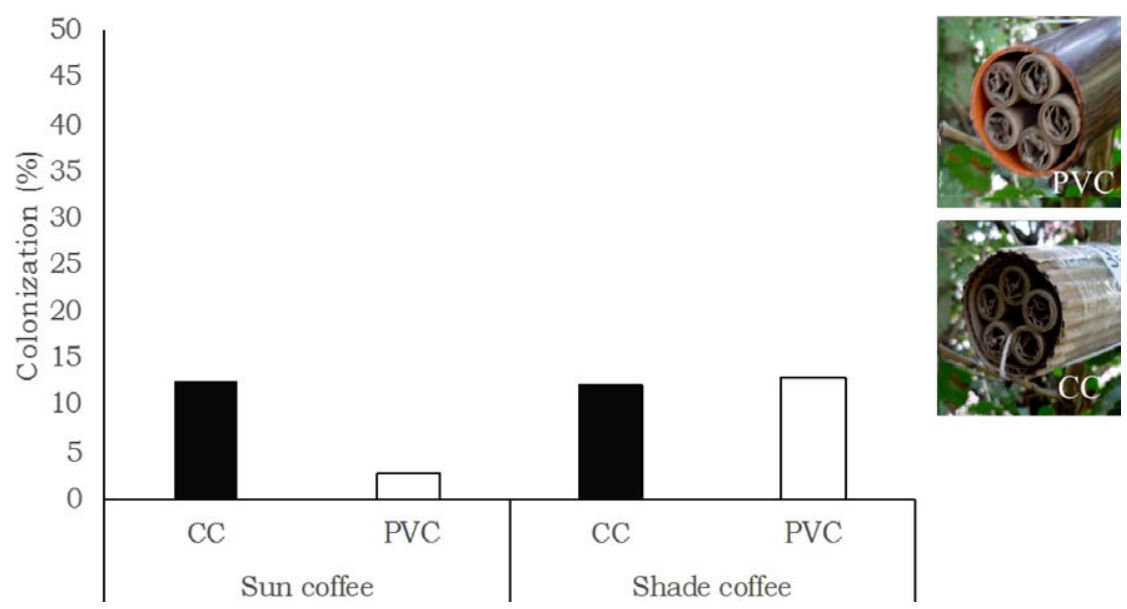

Figure 4. For Test 2, percentage of ant colonization in CC substrates with two types of cover, CC cover and polyvinylchloride cover (PVC) on shade-grown and sun-grown coffee plantations.

Test 3

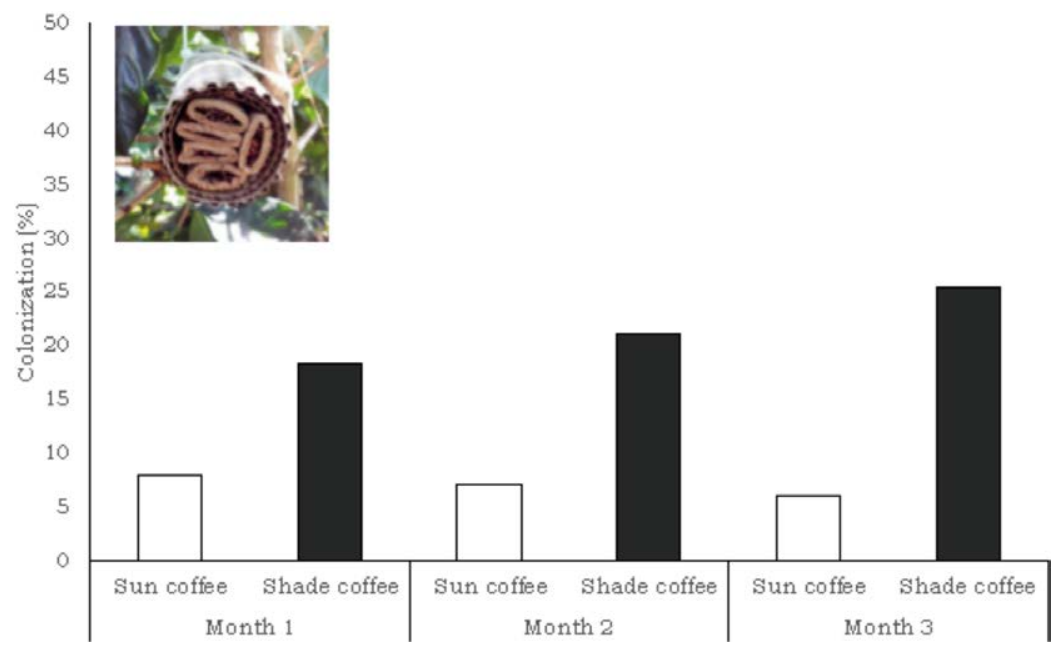

Figure 5. Percentage of ant colonization on shade-grown and sun-grown coffee plantations over a three-month period in Test 3. The substrate was mainly made of corrugated cardboard (CC). An increase in the colonization of shade-grown coffee plantations was observed over time, whereas colonization remained stable on the sun-grown coffee plantations. 
in general, there is a monotonal reduction of ant richness with altitude (Fisher, 2010). Ants are also sensitive to environmental conditions (Fisher, 2010). The general low ant nesting activity may also be explained by the extraordinarily dry conditions during the test period which coincided with the lowest colonization rates experienced in Test 2. This test occurred during the driest season of the year, from July to September, when higher temperatures and lower precipitation were recorded. Such environmental conditions may have affected the ants, since they are sensitive to microhabitat conditions (Perfecto and Vandermeer, 1996) Furthermore, the noteworthy colonization by other arthropods (mainly Araneae, Hymenoptera; Crabronidae, and Blattodea. See Table S3) during the dry season may have fostered interspecific competition for the artificial substrates.

Substrate materials and their configuration affected colonization by ants. Although we could not prove a relationship between ant size and substrate configuration, it is possible that the smaller entrances in CC filtered certain ant species; therefore, smaller ants like $N$. asper and C. crinosa were more capable of nesting in this substrate, while larger ant Camponotus species preferred CT with larger entrances. Possibly, arboreal ants such as $N$. asper and $C$. crinosa preferred CC because they closely resembled their natural nesting habitats in cavities in branches and bark (Tschinkel, 2002; Longino, 2003), while Camponotus are found nesting in hollow twigs from living and dead tree branches (Longino, 2006; Yamamoto \& Del Claro, 2008). Therefore, providing more heterogeneous substrates may allow for greater diversity due to niche differentiation in the ant community colonizing the artificial substrates, as suggested by Jimenez-Soto and Philpott (2015).
Despite a trend towards increasing species richness among ants nesting in shade-grown coffee in Test 1 and 2, no solid evidence was found that crop management type influenced substrate colonization or the number of ant species that colonized. One would expect colonization of artificial substrates to be higher in sun-grown coffee, where nesting resources for ants are scarce, as suggested by Armbrecht et al. (2006) and Philpott and Foster (2005). However, in this study, the most abundant and frequent species present in both sun-grown and shade-grown coffee (also found by Escobar et al., 2020, using tuna bait at the same study site) did not necessarily colonize the substrates, suggesting that colonization was more related to idiosyncratic preferences of a small-sized ant species present on both types of coffee plantations. Thus, the dominance of $N$. asper, Crematogaster crinosa and Camponotus sp. 1 colonizing substrates in both types of coffee plantations explained the lack of differences between sun-grown and shade-grown coffee. Philpott and Foster (2005) found that Nesomyrmex sp. showed the greatest colonization (219 colonization events) of artificial substrates on shade-grown coffee plantations in Mexico.

No differences in internal temperatures were found between substrate types in shade-grown coffee (in Test 2) while statistical differences were actually detected between substrates in sun-grown coffee. This suggests that the temperature in PVC substrates in sun-grown coffee could be limiting the ability of ants to colonize, since ants in sun-grown coffee mainly colonized substrates with no PVC cover. The presence of tree cover may have buffered the effects of hot days and low precipitation, sustaining microclimatic conditions suitable for ant nesting in any type of substrate. 
Results from Test 3 showed an increase in substrate colonization over time in shade-grown, but not sun-grown, coffee. This suggests that the positive effects from adding artificial substrates is better in shade-grown coffee and is consistent with Armbrecht et al. (2006) and Philpott and Foster (2005), who found greater limitation for twig-nesting ants on sun-grown coffee plantations in Colombia and Mexico, respectively.

\section{Conclusions}

The three questions initially asked were answered in this study. Ants nested in artificial substrates; their nesting was slightly higher in corrugated cardboard (CC) and in shade-grown coffee, and increased over time. The provision of artificial substrates made with cardboard might help increase the number of colonization events, and possibly enhance biocontrol of the coffee berry borer bug (Hypothenemus hampei, Coleoptera: Curculionidae) by ants, as nesting ants of the genera Nesomyrmex and Crematogaster have been reported as natural enemies of this important pest. In order to increase nesting activity and potential pest control services on coffee plantation, we suggest combining $\mathrm{CC}$ with materials that provide diverse entrance sizes and configurational heterogeneity. Carefully choosing a protecting wrap for the substrates will be important on sun-grown coffee plantations during the dry season as microclimatic conditions cannot be buffered by the presence of a shade trees. Therefore, the use of PVC as a substrate cover should be avoided on sun-grown coffee plantations. Installation of artificial substrates during the rainy season is highly recommended.

\section{Funding}

COLCIENCIAS, National Basic Sciences Programme (Code 110656933821, RC Contract No. 0648-2013) and Universidad del Valle (VRI, code CI 7951) funded this study.

\section{Acknowledgements}

Maria Cristina Gallego, Ramon Velez and SUPRACAFE for logistic support.

\section{Conflict of interest}

The authors declare no competing interests.

\section{Author contribution statement}

The total contribution percentage for the conceptualization, preparation, and correction of this paper was as follows: A.J.L.D. 34 \%., S.E.R. $33 \%$ and I.A. $33 \%$.

\section{Data availability statement}

The data supporting the results of this study will be made available by the corresponding author, Armbrecht, I., upon reasonable request.

\section{References}

Antweb. (2014). Antweb (Webpage). California Academy of Sciences. Available at www. antweb.org/

Armbrecht, I. \& Perfecto, I. (2003). Litter-twig dwelling ant species richness and predation potential within a forest fragment and neighboring coffee plantations of contrasting habitat quality in Mexico. Agriculture, Ecosystems and Environment, 97(1-3), 107-115. doi: https:// doi.org/10.1016/S0167-8809(03)00128-2 
Armbrecht, I.; Perfecto, I.; \& Silverman, E. (2006). Limitation of nesting resources for ants in $\mathrm{Co}-$ lombian forests and coffee plantations. EcologicalEntomology, 31(5),403-410. doi:https:// doi.org/10.1111/j.1365-2311.2006.00802.x

Armbrecht, I.; Vandermeer, J.; \& Perfecto, I. (2004). Enigmatic biodiversity correlations: leaf litter ant biodiversity respond to biodiverse resources. Science, 304, 284-286. doi: https://doi. org/10.1126/science.1094981

Barroso, S. C.; Longui, E. L.; Fernandes, T. T.; Oliveira, C. M.; Ferreira, A. C.; Silva, R. R.; \& Morini, M. S. C. (2020). Twigs occupied by Pheidole Westwood, 1839: Is there a difference between species? Biota Neotropica, 20(2), e20190897. Doi: http://dx.doi. org/10.1590/1676-0611-bn-2019-0897

De la Mora, A.; García-Ballinas, J. A.; \& Philpott, S. (2015). Local, landscape, and diversity drivers of predation services provided by ants in a coffee landscape in Chiapas, Mexico. Agriculture, Ecosystems \& Environment, 201, 83-91. doi: https://doi.org/10.1016/j. agee.2014.11.006

Escobar-Ramírez, S.; Tscharntke, T.; Armbrecht, I., Torres, W.; \& Grass, I. (2020). Decrease of $\beta$-diversity, but not $\alpha$-diversity of ants in intensively managed coffee plantations. Insect Conservation and Diversity, 13(5), 445-455. doi: https://doi.org/10.1111/icad.12417

Fernández, F.; \& Palacio, E. (2003). Sistemática y filogenia de las hormigas: breve repaso a propuestas. In F. Fernández. Introducción a las hormigas de la región Neotropical. (pp. 29-44). Bogota, Colombia. doi: http://dx.doi. org/10.13140/2.1.1790.6248

Fisher, B. L. (2010). Chapter 2. Biogeography. In C. Lach; C. Parr, \& K. L Abbott (Eds.). Ant Ecology (pp. 18-37). Oxford University Press. New York. 402p.

Guzman, L.; Calvache, H.; Aldana, J.; \& Méndez, A. (1997). Manejo de Leptopharsa gibbicarina Froeschner (Hemiptera: Tingidae) con la hormiga Crematogaster sp. en una plantación de palma de aceite. PALMAS, 18(4), 19-26.

Hosang, M. L. A.; Schulze, C. H.; Tscharntke, T.; \& Buchori, D. (2010). The potential of artificial nesting sites for increasing the population density of the black cacao ants. Indonesian Journal of Agriculture, 3(1), 45-50.

IDEAM. (2015). Instituto de Hidrología, Meteorología y Estudios Ambientales (Webpage). Ministerio de Ambiente y Desarrollo Sostenible de Colombia. Available at www.ideam.gov.co/

Jha, S.; Bacon, C. M.; Philpott. S. M.; Méndez, V. E.; Läderach, P.; \& Rice, R. A. (2014). Shade coffee: update on a disappearing refuge for biodiversity. Bioscience, 64(5), 416-428. https:// doi.org/10.1093/biosci/biu038

Jiménez-Soto, E. \& Philpott, S. M. (2015). Size matters: nest colonization patterns for twig-nesting ants. Ecology and Evolution, 5(16), 3288-3298. doi: https://doi.org/10.1002/ ece3.1555.

Lach, C.; Parr, C.; \& Abbott, K. L. (Eds.). (2010). Ant Ecology. Oxford University Press. New York. 402p. https://doi.org/10.1093/ acprof:oso/9780199544639.001.0001

Longino, J. T. (2003). The Crematogaster (Hymenoptera, Formicidae, Myrmicinae) of Costa Rica. Zootaxa, 151, 1-150. https://doi. org/10.11646/zootaxa.151.1.1

Longino, J. T. (2006). New species and nomenclatural changes for the Costa Rican ant fauna (Hymenoptera: Formicidae). Myrmecologische Nachrichten, 8, 131-143. https://archive. org/details/ants_21107

Meneses-R, O. E. \& Armbrecht, I. (2018). Índice de intensificación agrícola y conservación vegetal en bosques y cafetales colombianos con diferentes estrategias de manejo. Caldasia, 40(1), 161-176. https://doi.org/10.15446/caldasia.v40n1.61284

Mottl, O.; Yombai, J.; Fayle, T. M.; Novotny, V.; \& Klimes, P. (2019). Experiments with artificial nests provide evidence for ant community stratification and nest site limitation in a tropical forest. Biotropica, 52(2), 277-287. https://doi.org/10.1111/btp.12684

Ocampo-López, O. L. \& Alvarez-Herrera, L. M. (2017). Tendencia de la producción y el consumo de café en Colombia. Apuntes del CENES, 36(64), 139-165. doi http://dx.doi. org/10.19053/01203053.v36.n64.2017.5419

Perfecto, I. \& Vandermeer, J. (1996). Microclimatic changes and the indirect loss of ant diversity in a tropical agroecosystem. Oecologia, 108, 577-582. https://doi.org/10.1007/ BF00333736

Perfecto, I.; Rice, R. A.; Greenberg, R.; \& Van der Voort, M. E. (1996). Shade coffee: a disappearing refuge for biodiversity. Bioscience, 46, 598-608. doi: https://doi. org/10.2307/1312989. 
Philpott, S. M. \& Armbrecht, I. (2006). Biodiversity in tropical agroforests and the ecological role of ants and ant diversity in predatory function. Ecological Entomology, 31, 369-377. https:// doi.org/10.1111/j.1365-2311.2006.00793.x

Philpott, S. M., \& Foster, P. F. (2005). Nest-site limitation in coffee agroecosystems: Artificial nests maintain diversity of arboreal ants. Ecological Applications, 15(4), 1478-1485. https://doi.org/10.1890/04-1496

$\mathrm{R}$ development core team. (2013). $R$ : A language and environment for statistical computing. R Foundation for Statistical Computing, Vienna, Austria. Available from: www.R-project.org/.

Tschinkel, W. R. (2002). The natural history of the arboreal ant, Crematogaster ashmeadi. Journal of Insect Science, 2(12), 1-15. https://doi. org/10.1673/031.002.1201
Vidal-Hernández, W. J., \& Armbrecht, I. (2009). Impacto de la adición de ramitas de bambú y de la exclusión de hormigas sobre la herbivoría de cafetales de sol y sombra en el Cauca (Colombia). Rev. Brasil. Agroecol, 4(2), 877-881.

Yamamoto, M. \& Del-claro, K. (2008). Natural history and foraging behavior of the carpenter ant Camponotus sericeiventris Guërin, 1838 (Formicinae, Campotonini) in the Brazilian tropical savanna. Acta Ethologica, 11(2), 55-65. https://doi.org/10.1007/ s10211-008-0041-6

Zar, J. H. (1999). Biostatistical Analysis. 4th edition. Prentice Hall, New Jersey.

\section{(c) (i) (3) $\Theta$}

Nesting of arboreal ants (Hymenoptera: Formicidae) in artificial substrates in coffee plantations in the Colombian (Andes Andrés Jireh López-Dávila • Selene Escobar-Ramírez • Inge Armbrecht) Uniciencia is protected by Attribution-NonCommercial-NoDerivs 3.0 Unported (CC BY-NC-ND 3.0) 


\section{Supplementary material}

Table S1. Microhabitat and arboreal species present in the coffee plantations under study.

The tree cover was recorded at each point of substrate placement. Depth of leaf litter, coffee density and arboreal species are included (Meneses \& Armbrecht, 2018). Average values $\pm S D$ are also presented. *One or two trees per plantations and usually planted at the borders.

\begin{tabular}{|c|c|c|c|c|c|c|}
\hline Coffee plot & $\begin{array}{l}\text { Tree } \\
\text { cover } \\
(\%)\end{array}$ & $\begin{array}{c}\text { Temperature } \\
\left({ }^{\circ} \mathrm{C}\right)\end{array}$ & $\begin{array}{c}\text { Relative } \\
\text { humidity } \\
(\%)\end{array}$ & $\begin{array}{l}\text { Leaf litter } \\
\text { depth } \\
\text { (cm) }\end{array}$ & $\begin{array}{c}\text { Density } \\
\text { (coffee shrubs } \\
\text { number } / 5 \mathbf{m}^{2} \text { ) }\end{array}$ & Tree species \\
\hline $\begin{array}{l}\text { Sun-grown } \\
\text { coffee } 1\end{array}$ & $1.5( \pm 6.2)$ & $32.3( \pm 3.5)$ & $\begin{array}{c}40.8 \\
( \pm 10.6)\end{array}$ & 3.94 & 52 & $\begin{array}{l}\text { Persea americana, } \\
\text { Erythrina edulis* }\end{array}$ \\
\hline $\begin{array}{l}\text { Sun-grown } \\
\text { coffee } 2\end{array}$ & $\begin{array}{c}17.2 \\
( \pm 26.8)\end{array}$ & $24.8( \pm 2.0)$ & $63.8( \pm 9.9)$ & 1 & 43 & Persea americana* \\
\hline $\begin{array}{l}\text { Sun-grown } \\
\text { coffee } 3\end{array}$ & 0 & $31.0( \pm 3.0)$ & $46( \pm 11.8)$ & 3.29 & 43 & Psidium guajava* \\
\hline $\begin{array}{l}\text { Shade-grown } \\
\text { coffee } 1\end{array}$ & $\begin{array}{c}40.7 \\
( \pm 34.1)\end{array}$ & $30.5( \pm 0.9)$ & $29.6( \pm 5.4)$ & 4.18 & 35 & $\begin{array}{l}\text { Quercus humboldtii, } \\
\text { Pinus patula, Cecro- } \\
\text { pia telealba, Inga } \\
\text { edulis }\end{array}$ \\
\hline $\begin{array}{l}\text { Shade-grown } \\
\text { coffee } 2\end{array}$ & $\begin{array}{c}36.7 \\
( \pm 35.5)\end{array}$ & $25.6( \pm 0.8)$ & $39.2( \pm 4.6)$ & 6.15 & 45 & $\begin{array}{l}\text { Pinus patula, } \\
\text { Cecropia telealba, } \\
\text { Nectandra latifolia, } \\
\text { Quercus humboldtii }\end{array}$ \\
\hline $\begin{array}{l}\text { Shade-grown } \\
\text { coffee } 3\end{array}$ & $\begin{array}{c}49.2 \\
( \pm 39.0)\end{array}$ & $26.6( \pm 0.4)$ & $40.2( \pm 2.2)$ & 5.1 & 42 & $\begin{array}{l}\text { Pinus patula, } \\
\text { Cecropia telealba, } \\
\text { Nectandra latifolia }\end{array}$ \\
\hline
\end{tabular}

Table S2. Inner temperatures inside the artificial substrates taken in five pairs of substrates at each of the coffee plantations. $N=15$. Fourth column denotes the test from samples within each coffee management type (sun-grown coffee plantations or shade-grown coffee plantations).

\begin{tabular}{lccc}
\hline \multicolumn{1}{c}{ Coffee plantation } & $\mathbf{C C}\left({ }^{\circ} \mathbf{C}\right)$ & PVC $\left({ }^{\circ} \mathbf{C}\right)$ & $\begin{array}{c}\text { T test between same type of } \\
\text { management }\end{array}$ \\
\hline Sun-grown coffee 1 & $26,18( \pm 0,54)$ & $26,68( \pm 0,55)$ & \\
Sun-grown coffee 2 & $27,04( \pm 0,28)$ & $27,42( \pm 0,35)$ & $\mathrm{t}_{(14)}=-2,28 ; \mathrm{p}=0,0298$ \\
Sun-grown coffee 3 & $26,68( \pm 0,24)$ & $27,04( \pm 0,21)$ & \\
Shade-grown coffee 1 & $23,52( \pm 0,55)$ & $23,56( \pm 0,54)$ & \\
Shade-grown coffee 2 & $23,12( \pm 0,22)$ & $23,2( \pm 0,23)$ & $\mathrm{t}_{(14)}=0,183 ; \mathrm{p}=0,855$ \\
Shade-grown coffee 3 & $26,26( \pm 0,23)$ & $26,38( \pm 0,51)$ & \\
\hline
\end{tabular}


Table S3. Number of artificial substrates colonized by other arthropods than ants in test 2. The bees of the family Crabronidae were found to have the highest colonization events in the Corrugated Cover (CC) and PVC Cover (PVC) substrates.

\begin{tabular}{llll}
\hline \multicolumn{1}{c}{ Tree cover } & \multicolumn{1}{c}{ Other arthropods colonizing substrates } & PVC & CC \\
\hline Sun-grown & Arachnida: Araneae & 1 & 0 \\
coffee & Blattodea: Blattoidea (Eggs) & 1 & 2 \\
& Trypoxylon sp. (Hymenoptera: Crabronidae) & 1 & 1 \\
Shade-grown & Arachnida: Araneae & 2 & 0 \\
coffee & Trypoxylon sp. (Hymenoptera: Crabronidae) & 3 & 2 \\
& Total & $\mathbf{8}$ & $\mathbf{5}$ \\
\hline
\end{tabular}

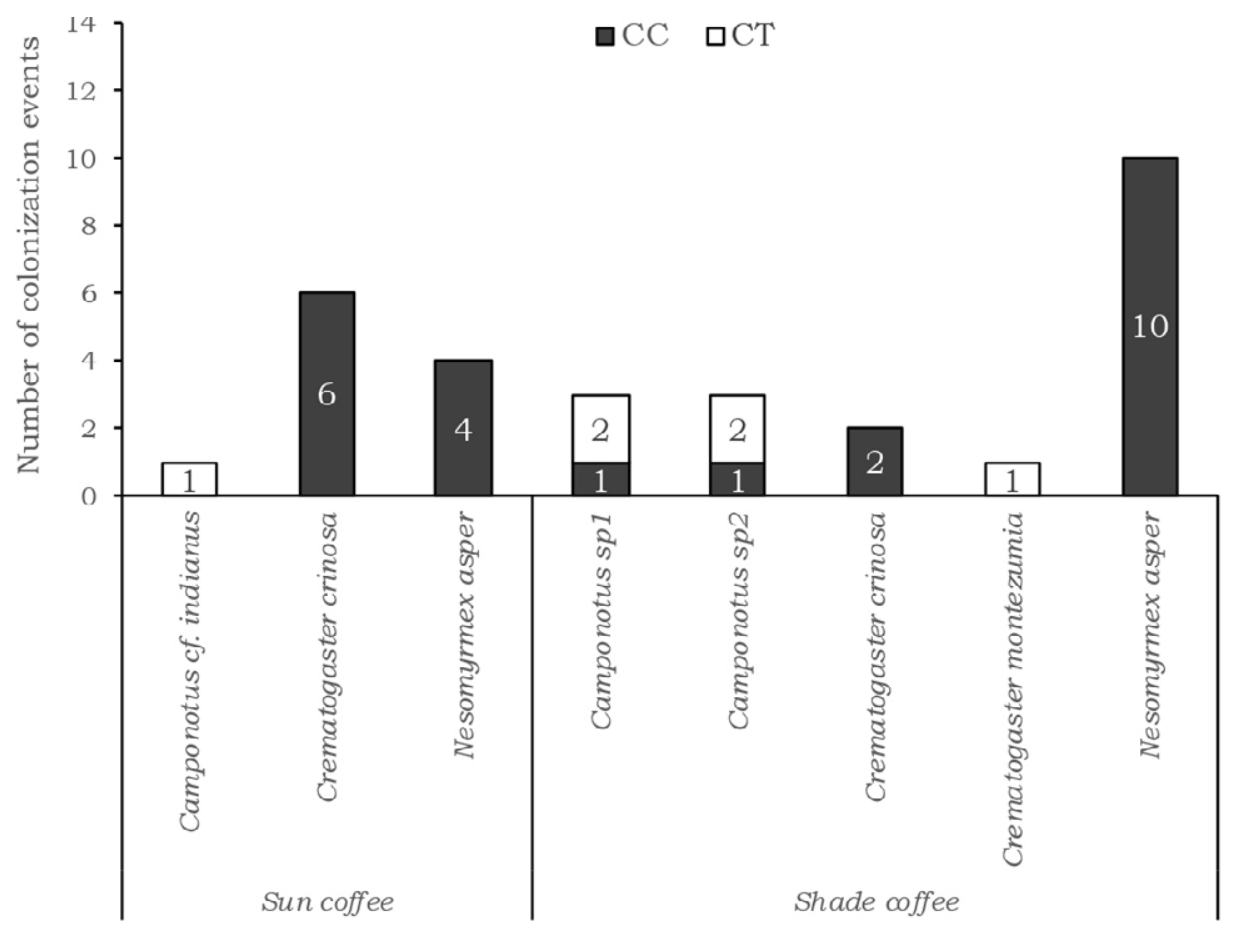

Figure S1. Colonization events by the different ant species established in substrates made by a polyvinyl chloride cover and filled with two different types of substrates: CC and CT, in sun-grown and shade-grown coffee plots, for test 1. 
- $\mathrm{CC}$ 口PC

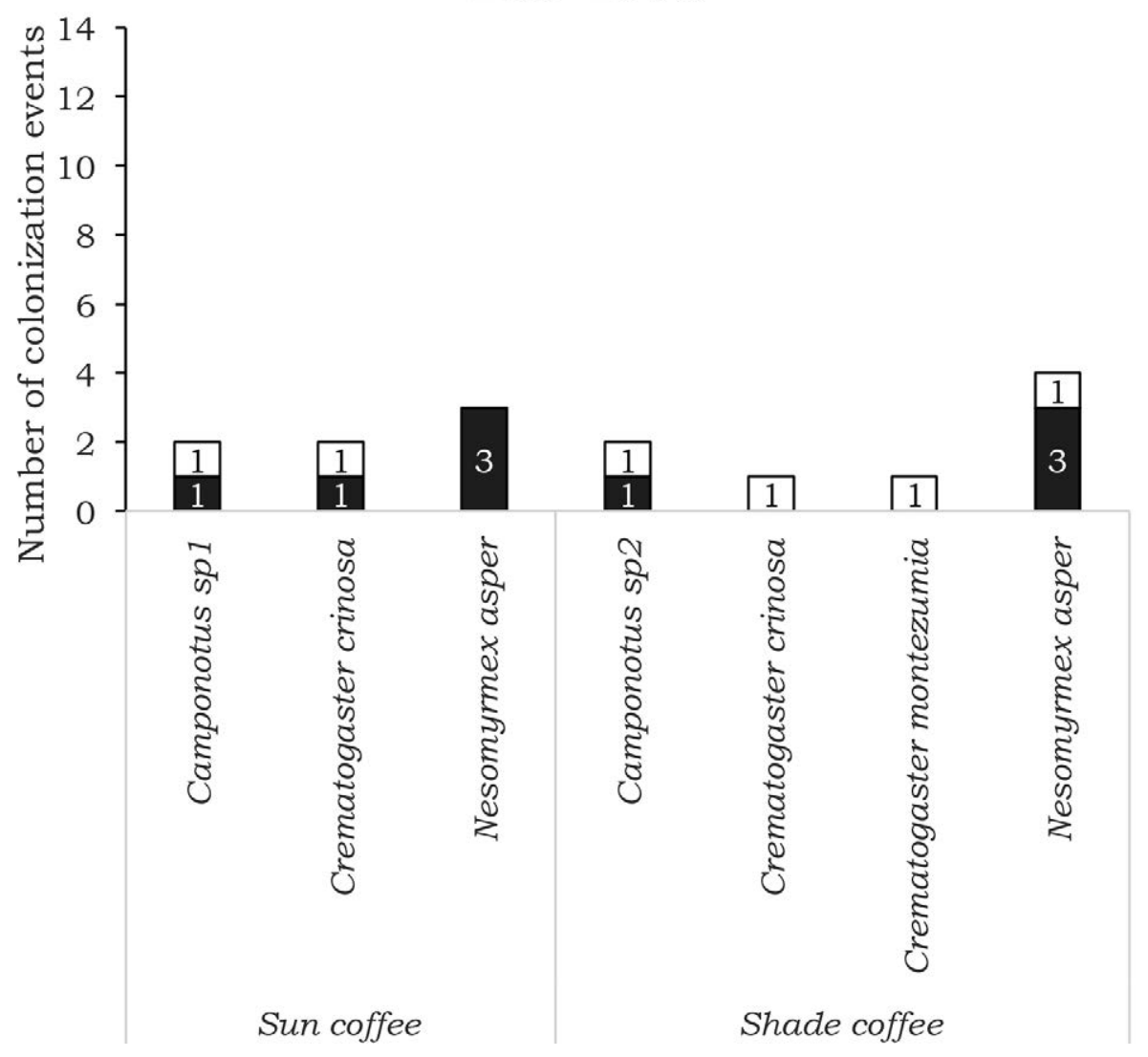

Figure S2. Colonization events by different ant species established in CC cover (CC-black) and polyvinylchloride cover (PVC-white) substrates, for test 2. A greater colonization of Nesomyrmex asper was observed in shade-grown plantations (CC) and of N. asper in sun-grown coffee (CC). N. asper colonized $37.5 \%$ of CC and of $12.5 \%$ in PVC. This was followed by Camponotus sp. 2 (12.5\% and $12.5 \%$ respectively). Both C. crinosa and C. montezumia showed a colonization of $12.5 \%$ in CC. In sun-grown coffee plantations $N$. asper occupied $60 \%$ (only CC), followed by C. crinosa ( $20 \%$ in both CC and PVC). 

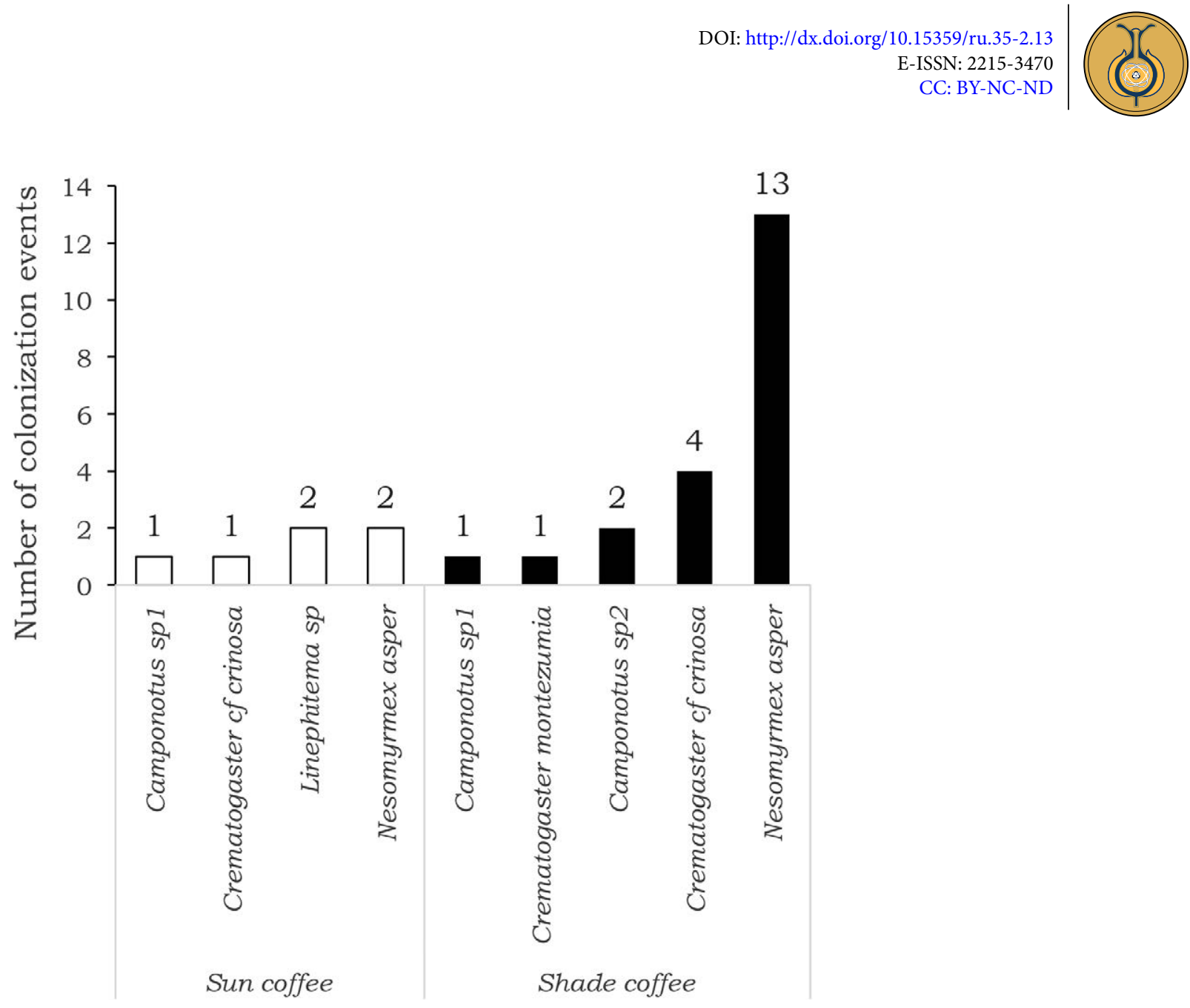

Figure S3. Ant species colonizing artificial substrates made of CC in shade-grown and sun-grown coffee plantations, during the monitoring of colonization in the test 3. Nesomyrmex asper is the species showing the greatest colonization, with an average of 15 colonization events during the 3 months of monitoring. 